\title{
Synthesis of Octahydro- and Decahydroquinolines by a One-Pot Cascade Reaction of Tetrasubstituted Enecarbamate
}

\section{$\operatorname{AUTHOR}(S):$}

Kurose, Tomohiro; Tsukano, Chihiro; Takemoto, Yoshiji

\section{CITATION:}

Kurose, Tomohiro ...[et al]. Synthesis of Octahydro- and Decahydroquinolines by a OnePot Cascade Reaction of Tetrasubstituted Enecarbamate. Organic Letters 2017, 19(18): $4762-4765$

ISSUE DATE:

2017-09-15

URL:

http://hdl.handle.net/2433/235944

\section{RIGHT:}

This document is the Accepted Manuscript version of a Published Work that appeared in final form in Organic Letters, copyright $\odot$ American Chemical Society after peer review and technical editing by the publisher. To access the final edited and published work see https://doi.org/10.1021/acs.orglett.7b02122;; This is not the published version. Please cite only the published version.; この論文は出版社版でありません。引用の際には出版社版をご磼認じ利用ください。 


\title{
Synthesis of Octahydro- and Decahydro-Quinolines by a One-Pot Cascade Reaction of Tetrasubstituted Enecarbamate
}

\author{
Tomohiro Kurose, Chihiro Tsukano,* and Yoshiji Takemoto* \\ Graduate School of Pharmaceutical Sciences, Kyoto University, Yoshida, Sakyo-ku, Kyoto 606-8501, Japan
}

Supporting Information Placeholder
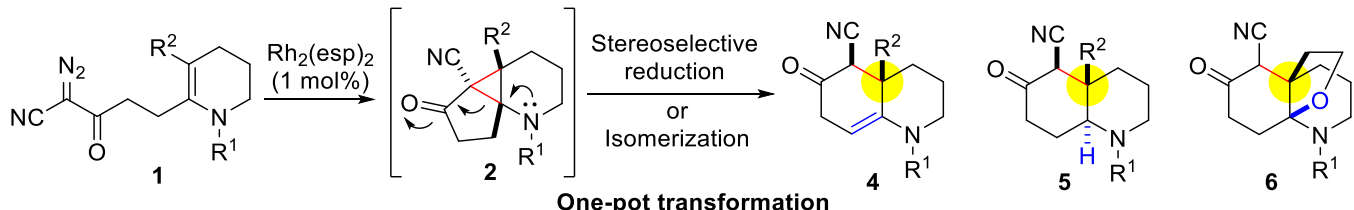

ABSTRACT: A transition metal catalyzed-cyclopropanation followed by ring-opening was investigated for the synthesis of octahydroquinolines $\mathbf{4}$ and decahydroquinolines $\mathbf{5}$ having a quaternary carbon center at the angular position, which are core structures of the fawcettimine-type alkaloids. A tandem reaction was also established for the synthesis of decahydroquinolines $\mathbf{5}$ and the tricyclic compound $\mathbf{6}$ through an iminium ion intermediate, readily produced by acidic treatment of cyclopropane 2.

Fawcettimine, isolated from Lycopodium fawcetti by Burnell and co-workers in 1959, is one of the representative Lycopodium alkaloids (Figure 1 ). ${ }^{1}$ It is one of more than 80 congeners reported to date, that include fawcettidine, ${ }^{1,2}$ macleanine, ${ }^{3}$ and squarrosusine $\mathrm{B}^{4}{ }^{4}$ each of which belong to the fawcettimine class of alkaloids. Recently, new members of this alkaloid class, such as lyconesidines, ${ }^{5}$ have been found in related species. Among these compounds, a complex tetracyclic skeleton is common, and the structural diversity mainly derives from the oxidation level and substituents on the B and D rings. ${ }^{6}$ Because of its unique tetracyclic structure, many groups are engaged in synthetic studies of the fawcettiminetype alkaloids. ${ }^{7,8}$ The main focus of these studies has been the synthesis of the hydrindane skeleton (B and D rings), and they are based on Inubushi and Heathcock's pioneering work. ${ }^{8 \mathrm{p}, \mathrm{q}}$ As an exceptional strategy, Dake and Kozak reported Pt(II)catalyzed cyclization to construct an octahydroquinoline skeleton having a quaternary carbon ( $\mathrm{C}$ and $\mathrm{D}$ rings). ${ }^{8 \mathrm{n}}$ While Dake's synthesis proposed the possibility of an octahydroquinoline skeleton as a useful intermediate. Additionally, the
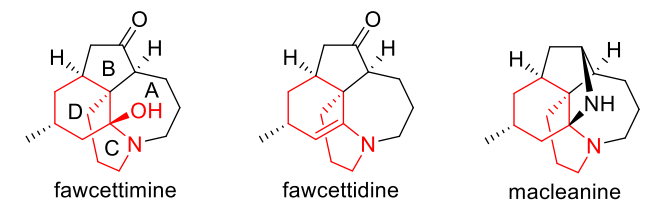

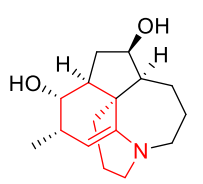

squarrosusine $B$

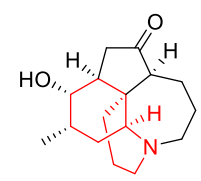

lyconesidine A

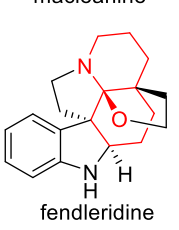

Figure 1. Fawcettimine-type alkaloids and a natural product containing both octa- and decahydroquinoline skeletons. skeleton has been found in various alkaloids such as fendleridine. ${ }^{9}$ Therefore, the development of a concise synthetic method for these skeleta would contribute to the synthesis of not only fawcettimine-type alkaloids but also related natural products.

Considering a synthesis of various analogs, we envisioned that an intramolecular cyclopropanation of tetrahydropyridine 1 followed by a ring-opening would give both octa- and decahydroquinoline $\mathbf{4}$ and $\mathbf{5}$, respectively (Scheme 1). That is, by introducing an electron-withdrawing group as a substituent $\left(\mathrm{R}^{3}\right.$ $=\mathrm{EWG}$ ), a ring-opening of cyclopropane 2 would readily produce an iminium intermediate $3,{ }^{10}$ which would be converted to 4 and 5 by a proton transfer and stereoselective reduction, respectively. It was expected that various substituents could be introduced into the obtained compounds $\mathbf{4}$ and 5 by using ketone functionality for the synthesis of fawcettimine-type alkaloids. Moreover, the iminium intermediate 3, derived from a substrate having a hydroxyethyl group $\left(\mathrm{R}^{2}=\mathrm{CH}_{2} \mathrm{CH}_{2} \mathrm{OH}\right)$, would be intramolecularly trapped with an alcohol to give a tricyclic compound $\mathbf{6}$, which can be found in a fendleridine skeleton. While there are many reports about cyclopropanation of mono-substituted enamides and enecarbamates, ${ }^{11,12}$ the number of reports decreases as the number of substituents increases. In the case of tetrasubstituted enamides and enecarbamates, pyrolysis of tosylhydrazone ${ }^{13 a}$ and formation of carbene from chloroform via treatment of a strong base ${ }^{13 \mathrm{~b}}$ were only employed for cyclopropanation. ${ }^{14}$ Thus, there is no example of the use of a transition metal-carbene complex. Herein, we report synthesis of octahydroquinolines $\mathbf{4}$, decahydroquinolines 5, and tricyclic compound $\mathbf{6}$ having a quaternary carbon center at the angular position via a transition metalcatalyzed cyclopropanation of tetrasubstituted enecarbamate and a ring-opening. 
Scheme 1. Synthetic strategy for diverse decahydro- and octahydro-quinolines.

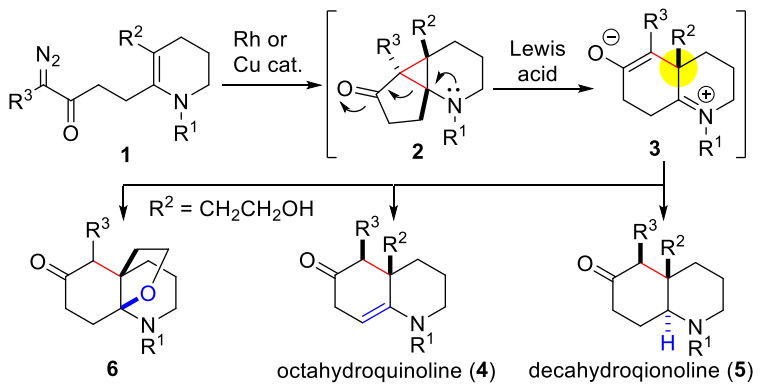

Initially, cyclization precursors $\mathbf{1 a}-\mathbf{h}$ were synthesized from 2-piperidone in six to eight steps including Heck or SuzukiMiyaura coupling, 1,4-reduction ${ }^{15}$ and diazotransfer ${ }^{16}$ (Scheme 2 ). We then investigated transition metal-catalyzed cyclopropanation of tetrasubstituted enecarbamate 1a. When compound 1a was treated with $\mathrm{Cu}(\mathrm{OTf})_{2}$, diketone 10 was obtained in $70 \%$ yield via a ring-opening of cyclopropane followed by hydrolysis (Table 1 , entry 1 ). Although $\mathrm{Cu}$ (hfacac) could be used for suppressing a ring-opening of cyclopropane, a part of the desired product $\mathbf{2 a}$ was converted to octahydroquinoline 4a, which was a mixture of keto- and enol-tautomers owing to the presence of an acidic proton (entry 2). In contrast, the use of rhodium catalysts, including $\mathrm{Rh}_{2}(\mathrm{OAc})_{4}$, $\mathrm{Rh}_{2}$ (cap) ${ }_{4},{ }^{17}$ and $\mathrm{Rh}_{2}(\mathrm{esp})_{2},{ }^{18}$ was effective for suppressing the undesired side reactions (entries 3-5). Specifically, $\mathrm{Rh}_{2}(\mathrm{esp})_{2}$ gave an hexa-substituted cyclopropane 2a in 57\% without compounds $\mathbf{4 a}$ and $\mathbf{1 0}$ (entry 5). For reproducible isolation of the product $\mathbf{2 a}$, addition of triethylamine into an eluent for silica gel column chromatography was important because $\mathbf{2 a}$ was not stable on silica gel.

We next focused on the selective transformation of the hexa-substituted cyclopropane $\mathbf{2 a}$ into octahydroquinoline $\mathbf{4 a}$ and decahydroquinoline 5a. When compound 2a was treated with trifluoroacetic acid (TFA) or $\mathrm{BF}_{3} \cdot \mathrm{OEt}_{2}$, ring-opening of cyclopropane was followed by a proton transfer to give compound $\mathbf{4 a}$ in excellent yields (Table 2, entries 1 and 2 ). These results indicated that cyclopropane $\mathbf{2 a}$ was readily cleaved to

Scheme 2. Synthesis of tetrasubstituted enecarbamate 1.

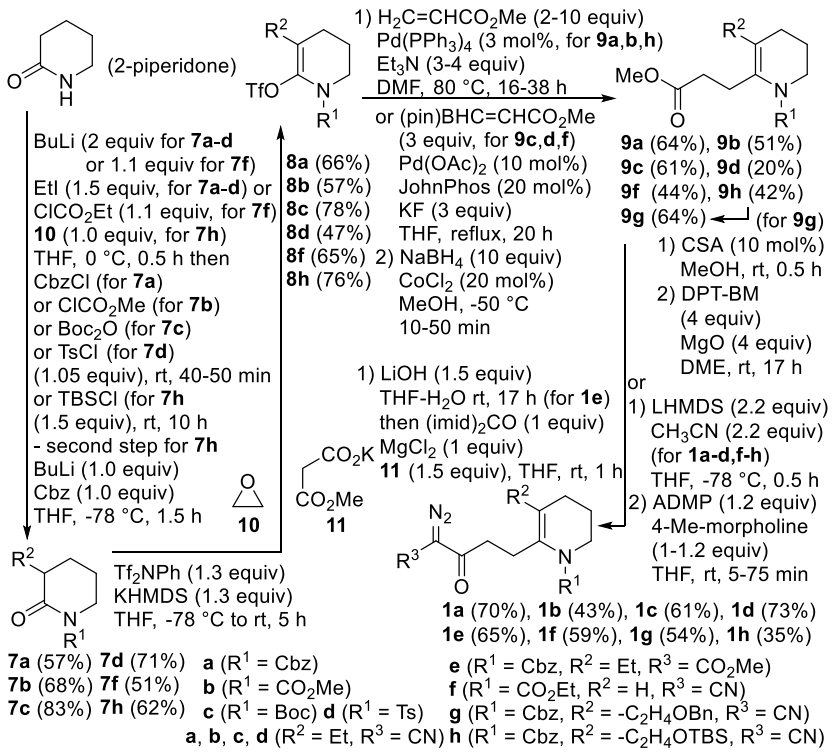

Table 1. Transition metal-catalyzed cyclopropanation of tetrasubstituted enecarbamate 1a.

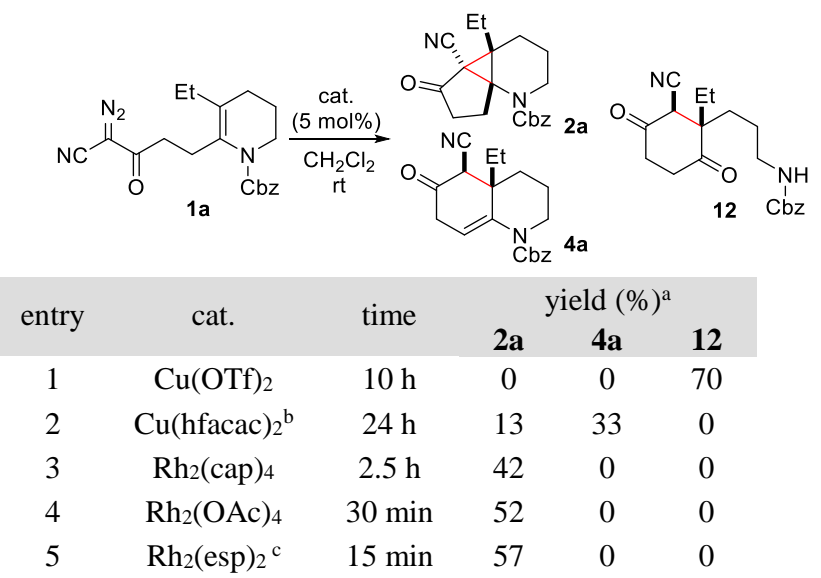

a. Isolated yield. b. $60 \mathrm{~mol} \%$. c. $0.1 \mathrm{~mol} \%$. Tf = triflate, hfacac $=$ hexafluoroacetylacetonato, cap $=$ caprolactamate, esp $=$ $\alpha, \alpha, \alpha^{\prime}, \alpha^{\prime}$-tetramethyl-1,3-benzenedipropionic acid.

produce an iminium ion such as 3 . Thus, reduction of the iminium ion was examined for obtaining decahydroquinoline 5a. When compound 2 was treated with $\mathrm{Et}_{3} \mathrm{SiH}, \mathrm{Ph}_{3} \mathrm{SiH}$, or $\mathrm{NaBH}_{3} \mathrm{CN}$ under acidic conditions (TFA), these reductions did not proceed (entries 3-5). In sharp contrast, use of $\mathrm{NaBH}(\mathrm{OAc})_{3}$ was effective, and the reaction gave the desired product $5 \mathbf{a}$ in $72 \%$ yield along with a small amount of $\mathbf{4 a}$ (entry 6). Several Lewis acids were also examined instead of TFA. In the case of $\mathrm{BF}_{3} \cdot \mathrm{OEt}_{2}$, the reaction gave $\mathbf{5 a}$, but the yield was low $(31 \%$, entry 7$)$. In contrast, a combination of $\mathrm{NaBH}(\mathrm{OAc})_{3}$ and other Lewis acids, including $\mathrm{Ti}(\mathrm{O} i \mathrm{Pr})_{4}$, $\mathrm{AlCl}_{3}, \mathrm{Sc}(\mathrm{OTf})_{3}$, and $\mathrm{MgBr}_{2} \cdot \mathrm{OEt}_{2}$, gave only octahydroquinoline 4a in low to moderate yields (entries 8-11). Therefore, $\mathrm{BF}_{3} \cdot \mathrm{OEt}_{2}$ was employed for opening the cyclopropane ring to access compound $\mathbf{4}$, and a combination of TFA and $\mathrm{NaBH}(\mathrm{OAc})_{3}$ was determined to provide the best conditions for the synthesis of compound $\mathbf{5}$. Reduction of the iminium intermediate 3a proceeded with excellent stereoselectivity because the reductant attacked from the less hindered face (Scheme 3). Because 5a was a mixture of keto- and enoltautomers, the stereochemistry of the trans-fused ring system was determined by NOESY experiments after formation of tert-butyldimethylsilyl (TBS) enol ether 13a (Scheme 3). For the synthesis of compound $\mathbf{5 a}$, compound $\mathbf{4 a}$ was also treated under the optimized reduction conditions (TFA and $\left.\mathrm{NaBH}(\mathrm{OAc})_{3}, \mathrm{rt}\right)$. However, the reaction did not proceed to give 5a. This result indicated that the iminium ion 3a was not produced from compound $\mathbf{4 a}$ under these mild conditions.

Table 2. Selective formation of octahydroquinoline $4 a$ and decahydroquinoline 5 a.

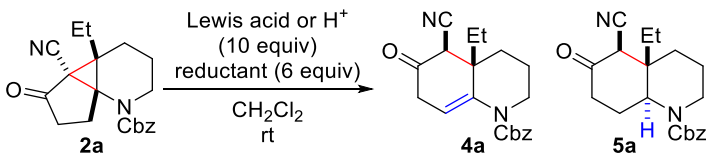

\begin{tabular}{|c|c|c|c|c|c|}
\hline \multirow{2}{*}{\multicolumn{2}{|c|}{ entry Lewis acid or $\mathrm{H}^{+}$}} & \multirow{2}{*}{ reductant } & \multirow{2}{*}{ time } & \multicolumn{2}{|c|}{ yield $(\%)^{\mathrm{a}}$} \\
\hline & & & & $4 a$ & $5 \mathbf{a}$ \\
\hline 1 & $\mathrm{TFA}^{\mathrm{b}}$ & none & $30 \mathrm{~min}$ & 96 & 0 \\
\hline 2 & $\mathrm{BF}_{3} \cdot \mathrm{OEt}_{2}{ }^{\mathrm{b}}$ & none & $30 \mathrm{~min}$ & 95 & 0 \\
\hline 3 & TFA & $\mathrm{Et}_{3} \mathrm{SiH}$ & $2 \mathrm{~h}$ & 56 & 0 \\
\hline
\end{tabular}




$\begin{array}{cccccc}4 & \mathrm{TFA} & \mathrm{Ph}_{3} \mathrm{SiH} & 5 \mathrm{~h} & 40 & 0 \\ 5 & \mathrm{TFA} & \mathrm{NaBH}_{3} \mathrm{CN} & 2 \mathrm{~h} & 17 & 0 \\ 6 & \mathrm{TFA} & \mathrm{NaBH}(\mathrm{OAc})_{3} & 2 \mathrm{~h} & 22^{\mathrm{c}} & 72^{\mathrm{c}} \\ 7 & \mathrm{BF}_{3} \cdot \mathrm{OEt}_{2}{ }^{\mathrm{d}} & \left.\mathrm{NaBH}^{\mathrm{O}} \mathrm{OAc}\right)_{3}{ }^{\mathrm{e}} & 11 \mathrm{~h} & 23^{\mathrm{c}} & 31^{\mathrm{c}} \\ 8 & \mathrm{Ti}(\mathrm{O} i \mathrm{Pr})_{4} & \mathrm{NaBH}(\mathrm{OAc})_{3} & 15 \mathrm{~min} & 29^{\mathrm{f}} & 0 \\ 9 & \mathrm{AlCl}_{3} & \mathrm{NaBH}(\mathrm{OAc})_{3} & 3 \mathrm{~h} & 59 & 0 \\ 10 & \mathrm{Sc}_{(\mathrm{OTf})_{3}} & \mathrm{NaBH}(\mathrm{OAc})_{3} & 2 \mathrm{~h} & 28 & 0 \\ 11 & \mathrm{MgBr}_{2} \cdot \mathrm{OEt}_{2} & \mathrm{NaBH}(\mathrm{OAc})_{3} & 3 \mathrm{~h} & 60 & 0\end{array}$

a. Isolated yield. b. 1 equiv. c. The yield was calculated by ${ }^{1} \mathrm{H}$ NMR. d. 6 equiv. e. 10 equiv. f. The starting material was recovered $(31 \%)$. TFA $=$ trifluoroacetic acid.

Scheme 3. Stereoselectivity of the reduction of iminium intermediate $3 \mathbf{a}$.
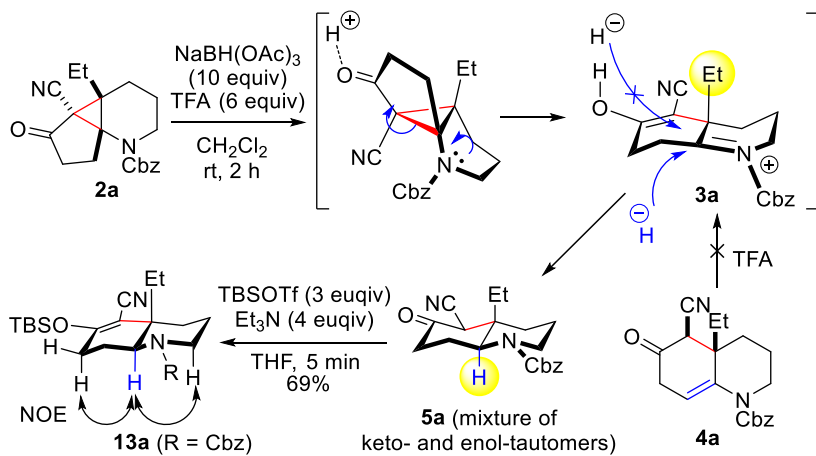

To determine the scope and limitations, the optimized conditions were applied for the synthesis of several octahydroquinolines $\mathbf{4 b} \mathbf{- 4 h}$ (Table 3). Cyclopropanation of substrates $\mathbf{1 b}$ and $\mathbf{1 c}$ having $\mathrm{CO}_{2} \mathrm{Me}$ and Boc group as protecting groups gave compounds $\mathbf{2 b}$ and $\mathbf{2 c}$ in moderate yields, respectively (entries 1 and 2 ). Compound $\mathbf{2 b}$ readily converted to octahydroquinoline $\mathbf{4 b}$ when treated with $\mathrm{BF}_{3} \cdot \mathrm{OEt}_{2}$. In the case of $\mathbf{2 c}$, $\mathrm{MgBr}_{2} \cdot \mathrm{OEt}_{2}$ was used instead of $\mathrm{BF}_{3} \cdot \mathrm{OEt}_{2}$ for suppressing the undesired deprotection of the Boc group. Compound $\mathbf{4 c}$ was obtained in excellent yield. Interestingly, the reaction of $\mathbf{1 d}$ with its tosyl group gave $\mathbf{4 d}$ in $76 \%$ yield without acidic treatment, as the corresponding cyclopropane $\mathbf{2 d}$ was easily cleaved (entry 3 ). The reaction of $\beta$-keto- $\alpha$-diazoester $1 \mathbf{e}$ did not give compound 2e. Thus a nitrile group is essential for this cyclopropanation (entry 4). The reaction of $\mathbf{1 f}$ did not give cyclopropane $2 \mathbf{f}$ because $\mathrm{C}-\mathrm{H}$ insertion was competitive (entry 5). Benzyl (Bn) and TBS groups were compatible under these reactions, and octahydroquinolines $4 \mathrm{~g}$ and $\mathbf{4 h}$ were obtained in $80 \%$ and quantitative yields, respectively (entries 6 and 7).

Table 3. Scope and limitations of synthesis of octahydroquinoline 4.

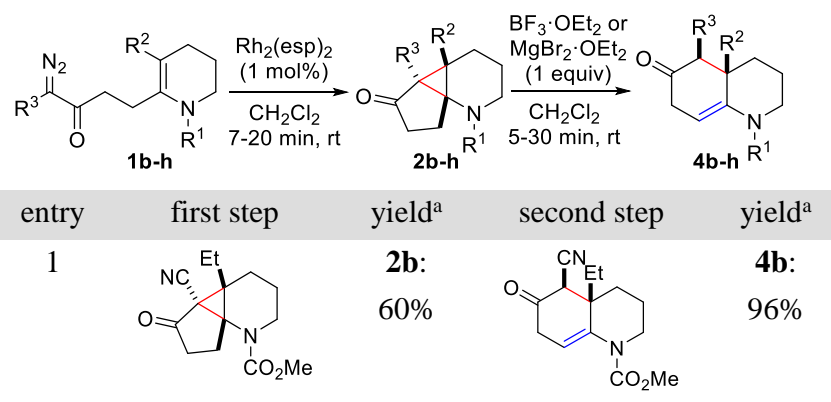

2

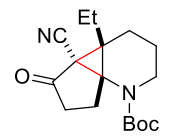

2c:

$50 \%$<smiles>CC1(C#N)C(=O)CC=C2N(C(=O)c3ccccc3)CCCC21C#N</smiles>

4c:

quant $\mathrm{b}^{\mathrm{b}}$
3

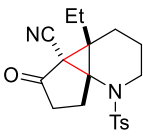

4

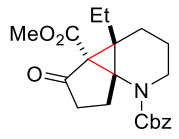

5

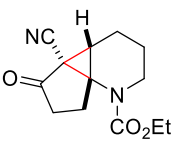

6

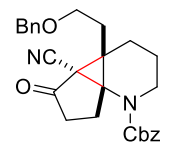

7

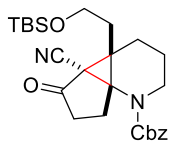

2d:<smiles>[Y5]N1CCCC2(C#N)C1=CCC(=O)C2C#N</smiles>

2e:<smiles>CCC1(C(=O)OC)CCCN(C(=O)OCc2ccccc2)C2=CCC(=O)CC21</smiles>

2f:<smiles>CCON1CCC[C@H]2C1=CCC(=O)C2C#N</smiles>

2g:

$49 \%$

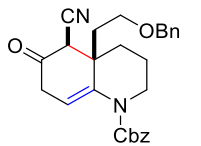

2h:

$52 \%$

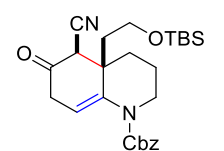

4d:

$76 \%$ c,d

4e:

4f:

4g:

$80 \%$

4h:

quant ${ }^{\mathrm{b}}$ a. Isolated yield. b. $\mathrm{MgBr}_{2} \cdot \mathrm{OEt}_{2}$ was used instead of $\mathrm{BF}_{3} \cdot \mathrm{OEt}_{2}$. c. Without acidic treatment. d. The reaction time was $35 \mathrm{~min}$. Bn = benzyl, TBS = tert-butyldimethylsilyl .

Because compound 2 was not stable as described above, a one-pot cyclopropanation/reductive ring-opening was attempted for the synthesis of decahydroquinolines $\mathbf{5}$. Treatment of $\mathbf{1 a}$ with $\mathrm{Rh}_{2}(\mathrm{esp})_{2}$ was followed by reductive ring-opening using TFA and $\mathrm{NaBH}(\mathrm{OAc})_{3}$ to give decahydroquinoline 5a in $48 \%$ yield, which was comparable to the yield of the stepwise procedure (Table 4, entry 1). Methoxycarbonyl and Boc groups were compatible under these conditions (entries 2 and 3). In the case of substrates having Bn and TBS groups, the desired decahydroquinolines $\mathbf{5 g}$ and $\mathbf{5 h}$ were obtained as major products, respectively, while the reductive ring-opening competed with formation of octahydroquinolines $4 \mathrm{~g}$ and $\mathbf{4 h}$.

Table 4. One-pot cyclopropanation and reductive ringopening for synthesis of decahydroquinoline 5 .

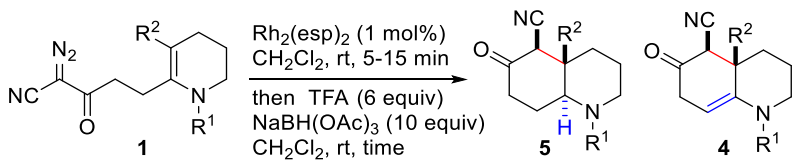

$\begin{array}{ccccccc}\text { entry } & \mathrm{R}^{1} & \mathrm{R}^{2} & \text { time } & \text { product } & \text { yield }(\%)^{\mathrm{a}} & \text { ratio }^{\mathrm{b}} \\ & & & \mathrm{5}+\mathbf{4} & \mathbf{5 : 4} \\ 1^{\mathrm{c}} & \mathrm{Cbz} & \mathrm{Et} & 2 \mathrm{~h} & \mathbf{5 a} & 48 & 4.0: 1 \\ 2^{\mathrm{d}} & \mathrm{CO}_{2} \mathrm{Me} & \mathrm{Et} & 50 \mathrm{~min} & \mathbf{5 b} & 64 & 7.3: 1 \\ 3^{\mathrm{d}} & \mathrm{Boc} & \mathrm{Et} & 45 \mathrm{~min} & \mathbf{5 c} & 77 & 6.5: 1 \\ 4 & \mathrm{Cbz} & \mathrm{CH}_{2} \mathrm{CH}_{2} \mathrm{OBn} & 8 \mathrm{~h} & \mathbf{5 g} & 47 & 3.3: 1 \\ 5^{\mathrm{d}} & \mathrm{Cbz} & \mathrm{CH}_{2} \mathrm{CH}_{2} \mathrm{OTBS} & 2 \mathrm{~h} & \mathbf{5 h} & 43 & 3.8: 1\end{array}$

a. Isolated yield. b. The ratio was calculated by ${ }^{1} \mathrm{H}$ NMR. c. 0.1 mol\% of $\mathrm{Rh}_{2}(\mathrm{esp})_{2}$ was used. d. $\mathrm{Rh}(\mathrm{OAc})_{2}$ was used instead of $\mathrm{Rh}_{2}(\mathrm{esp})_{2}$.

This one-pot procedure for decahydroquinolines 5 was extended to a one-pot synthesis of tricyclic compound $\mathbf{6}$ (Scheme 
4). Treatment of $\beta$-keto- $\alpha$-diazonitrile 1i with $\mathrm{Rh}_{2}(\mathrm{esp})_{2}$ followed by $\mathrm{BF}_{3} \cdot \mathrm{OEt}_{2}$ gave compound 6 via cyclopropanation in $66 \%$ yield. It is interesting that the cyclopropanation was the preferable process rather than $\mathrm{O}-\mathrm{H}$ insertion in the first step, and an iminium ion could be trapped without formation of enecarbamate in the second step. It was difficult to obtain compound 6 from octahydroquinoline $4 \mathbf{i}$ under mild conditions including treatment with $\mathrm{BF}_{3}$. $\mathrm{OEt}_{2}$ or CSA.

Scheme 4. One-pot synthesis of tricyclic compound 6.

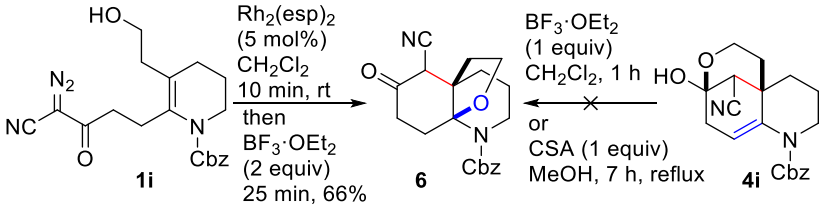

In summary, we have investigated a concise synthesis of octahydroquinolines $\mathbf{4}$ and decahydroquinolines $\mathbf{5}$ having a quaternary carbon center at the angular position via a one-pot reaction involving cyclopropanation and ring-opening. The use of Ts-protected ene-sulfonamide 1d was found to be effective for direct access to 4 . One-pot procedures for the synthesis of decahydroquinolines $\mathbf{5}$ and tricyclic compound $\mathbf{6}$ were also established. These methods would be powerful because a quaternary carbon center and a six-membered carbocycle were constructed at once. Synthesis of related alkaloids based on the developed strategy for decahydroquinolines $\mathbf{5}$ is now underway.

\section{ASSOCIATED CONTENT}

\section{Supporting Information}

The Supporting Information is available free of charge on the ACS Publications website. Experimental procedures, spectra data $\left({ }^{1} \mathrm{H}\right.$ and ${ }^{13} \mathrm{C}$ NMR, IR, and HRMS) (PDF)

\section{AUTHOR INFORMATION}

\section{Corresponding Author}

*E-mail: tsukano@pharm.kyoto-u.ac.jp

* E-mail: takemoto@ pharm.kyoto-u.ac.jp

Notes

The authors declare no competing financial interest.

\section{ACKNOWLEDGMENT}

This work was supported by the JSPS KAKENHI (GrantNo. JP17H05051), the Platform Project for Supporting Drug Discovery and Life Science Research from Japan Agency for Medical Research and Development (AMED).

\section{REFERENCES}

(1) (a) Burnell, R.H. J. Chem. Soc. 1959, 3091. (b) Inubushi, Y.; Ishii, H.; Harayama, T.; Burnell, R.H.; Ayer, W.A.; Altenkirk, B. Tetrahedron Lett. 1967, 8, 1069

(2) (a) Burnell, R.H.; Chin, C.G.; Mootoo, B.S.; Taylor, D.R. Can. J. Chem. 1963, 41, 3091. (b) Ishii, H.; Yasui, B.; Nishino, R.-I.; Harayama, T.; Inubushi, Y. Chem. Pharm. Bull. 1970, 18, 1880.

(3) Ayer, W. A.; Ma, Y.-T.; Liu, J.-S. Huang, M.-F.; Schultz, L.W Clardy, J. Can. J. Chem, 1994, 72, 128.

(4) Li, P.; Huang, W.; Zhuo, J.; Guo, Z.; Cao, W.; Xu, L.; Ma, L.; Chen, Z.-E.; Kennelly, E. J.; Wu, S.-B.; Long, C. Tetrahedron, 2015, 71, 5308 .

(5) Hirasawa, Y.; Morita, H.; Kobayashi, J. Tetrahedron 2002, 58, 5483
(6) For reviews of Lycopodium alkaloids, see: (a) Ayer, W.A. Nat Prod. Rep. 1991, 8, 455. (b) Ma, X.; Gang, D.R. Nat. Prod. Rep. 2004, 21, 752. (c) Hirasawa, Y.; Kobayashi, J.; Morita, H. Heterocycles 2009, 77, 679.

(7) For recent reviews of synthesis of fawcettimine-type alkaloids, see: (a) Murphy, R.A.; Sarpong, R. Chem. Eur. J. 2014, 20, 42. (b) Nakayama, A.; Kitajima, M.; Takayama, H. Synlett, 2012, 23, 2014. (c) Wang, X.; Li, H.; Lei, X. Syneltt, 2013, 24, 1032.

(8) Selected examples of synthesis of fawcettimine-type alkaloids, see: (a) Tanimura, S.; Yokoshima, S.; Fukuyama, T. Org. Lett. 2017, 19, 3684. (b) Hong, B.; Li, H.; Wu, J.; Zhang, J.; Lei, X. Angew. Chem. Int. Ed. 2015, 54, 1011. (c) Zaimoku, H.; Taniguchi, T. Chem. Eur. J. 2014, 20, 9613. (d) Zhang, J.; Wu, J.; Hong, B.; Ai, W.; Wang, X.; Li, H.; Lei, X. Nat. Commun. 2014, 5, 4614. (e) Hou, S.-H.; Tu, Y.-Q.; Liu, L.; Zhang, F.-M.; Wang, S.-H.; Zhang, X.-M. Angew. Chem. Int. Ed. 2013, 52, 11373. (f) Itoh, N.; Iwata, T.; Sugihara, H.; Inagaki, F.; Mukai, C. Chem. Eur. J. 2013, 19, 8665. (g) Zeng, C.; Zheng, C.; Zhao, J.; Zhao, G. Org. Lett. 2013 , 15, 5846. (h) Ge, H. M.; Zhang, L.-D.; Tan, R. X.; Yao, Z.-J. J. Am. Chem. Soc. 2012, 134, 12323. (i) Pan, G.; Williams, R. M. J. Org. Chem. 2012, 77, 4801. (j) Li, H.; Wang, X.; Lei, X. Angew. Chem. Int. Ed. 2012, 51, 491. (k) Nakayama, A.; Kogure, N.; Kitajima, M.; Takayama, H. Angew. Chem. Int. Ed. 2011, 50, 8025. (1) Yang, Y.-R.; Shen, L.; Huang, J.-Z.; Xu, T.; Wei, K. J. Org. Chem. 2011, 76, 3684. (m) Jung, M.E.; Chang, J.J. Org. Lett. 2010, 12, 2962. (n) Kozak, J.A.; Dake, G.R. Angew. Chem. Int. Ed. 2008, 47, 4221. (o) Linghu, X.; Kennedy-Smith, J.J.; Toste, F.D. Angew. Chem. Int Ed. 2007, 46, 7671. (p) Heathcock, C.H.; Smith, K.M.; Blumenkopf, T.A. J. Am. Chem. Soc. 1986, 108, 5022. (q) Harayama, T. Takatani, M. Inubushi, Y. Chem. Pharm. Bull. 1980, 28, 2394.

(9) (a) Brown, K.S.; Budzikiewicz, H.; Djerassi, C. Tetrahedron Lett. 1963, 4, 1731. (b) Burnell, R.H.; Medina, J.D.; Ayer, W.A Can. J. Chem. 1966, 44, 28.

(10) For recent reviews of ring-opening of aminocyclopropane with an electron withdrawing group, see: (a) Grover, H.K.; Emmett, M.R.; Kerr, M.A. Org. Biomol. Chem. 2015, 13, 655. (b) Schneider, T.F.; Kaschel, J.; Werz, D.B. Angew. Chem. Int. Ed. 2014, 53, 5504.

(11) For reviews of cyclopropanation of enamides and enecarbamate, see: (a) Courant, T.; Dagousset, G.; Masson, G. Synthesis, 2015, 47, 1799. (b) Lebel, H.; Marcoux, J.-F.; Molinaro, C.; Charette, A.B. Chem. Rev. 2003, 103, 977.

(12) For examples regarding cyclopropanation of enamides and enecarbamate, see: (a) Song, Z.; Lu, T.; Husng, R.P. Al-Rashid, Z.F.; Ko, C.; Tang, Y. Angew. Chem. Int. Ed. 2007, 46, 4069. (b) Lu, T.; Song, Z.; Hsung, R. P. Org. Lett. 2008, 10, 541. (c) De Simone, F.; Gertsch, J.; Waser, J. Angew. Chem. Int. Ed. 2010, 49, 5767. (d) Wenkert, E.; Hudlicky T. J. Org. Chem. 1988, 53, 1953. (e) Csuk, R.; von Scholz, Y. Tetrahedron 1994, 50, 10431.

(13) (a) Remy, C.C.; King, S.W.; Cochran D.; Springer, J.P.; Hirshfield, J. J. Org. Chem. 1985, 50, 4120. (b) Padwa, A.; Rashatasakhon, P.; Ozdemir, A.D.; Willis, J. J. Org. Chem. 2005, 70, 519.

(14) There are a few reports if cyclopropanation of an electron-rich indole ring having two substituent at $\mathrm{C} 2$ and $\mathrm{C} 3$ positions is included, see: (a) Huang, H.-X.; Jin, S.-J.; Gong, J.; Zhang, D.; Song, H.; Qin, Y. Chem. Eur. J. 2015, 21, 13284. (b) Zhang, B.; Wee, A. G.H. Chem. Commun, 2008, 4837. (c) Shen, L.; Zhang, M.; Wu, Y, Qin, Y. Angew. Chem. Int. Ed. 2008, 47, 3618. (d) Zhang, M.; Huang, X.; Shen, L. Qin, Y. J. Am. Chem. Soc. 2009, 131, 6013. (e) Salim, M.; Capretta, A. Tetrahedron 2000, 56, 8063.

(15) Geiger, C.; Kreitmeier, P.; Reiser, O. Adv. Synth. Catal., 2005, 347, 249.

(16) Kitamura, M.; Tashiro, N.; Miyagawa, S.; Okauchi, T. Synthesis, 2011, 1037.

(17) Padwa, A.; Austin, D.J.; Hornbuckle, S.F.; Semones, M.A.; Doyle, M.P.; Protopopova, M.N. J. Am. Chem. Soc., 1992, 114, 1874

(18) Espino, C.G.; Fiori, K.W.; Kim, M.; DuBois, J. J. Am. Chem. Soc. 2004, 126, 15378. 